\title{
Forest Condition and Management in the Swedish Forest commons
}

\begin{abstract}
All over the world, we can witness an awakening interest and recognition of community forest ownership and management as a tool for enhanced local development. Their management are often based on old traditions, close bonds between the local community and the nature resource, long-term thinking and flexibility; all important factors as regards natural resource management. The interest may indicate the acknowledgment of the important role they have played, not only in the past and present, but also their potential future importance for local development and survival both in the South and the North.
\end{abstract}

In the middle of the 19-th century the Swedish authorities feared for irreversible depletion and degradation of the forests in the northern part of the country. It was the forest companies who showed a rather aggressive interest in the forests. At that time the state, who still was the officially owner of the forestland in the north, was in the process of finalizing the delimitationprocess that had started already in the seventeenths century and involved the fixing of boundaries between the Crown land and other. However, the authorities were anxious that once the forests had been officially parcelled out to the farmers the forests would be exploited by the forest companies. This would challenge the Crowns' intentions for a sustainable use of the forests as well as undermine the base for the farmers and the parish' economy not to mention a reduction of state tax incomes.

The remedy selected was the introduction of Forest Commons. Each farmer would get one part of their forest share as individual private land and the other as a share in a jointly owned area, a Forest Common. They are all regulated by the same national laws but in addition, each forest possesses its own by-law.

During the period 1861-1918, 33 different Forest Commons were established in the northern part of Sweden. Today they cover about 541000 ha of productive forestland held among 25000 shareholders. 
In 1983 a Recommendation from the Swedish Commission on Collectively-Owned Forest Land was published, where it among other things, was concluded that "Swedish forest expertise" regarded the Swedish Forest Commons to be "among the best managed forests in the country taken into consideration their prerequisites". This statement can be interpreted in a number of ways. However, my hypothesis was that the state of these forests differed from the surrounding forests' without putting any value into what is "best managed". A comparison between the Forest Commons and other forests in the same municipalities was carried out. The forests were for this purpose divided into four groups; Private forests, Company forests, Forest Commons and other types of commons on which a number of forest parameters were compared. Data used originated from the Swedish National Forest Inventory's databases 1998 - 2002. 


\title{
Forest Condition and Management in the Swedish Forest commons
}

\author{
Eva Holmgren ${ }^{1}$, Gun Lidestav ${ }^{2}$ and Göran Kempe ${ }^{3}$
}

\section{The Forest commons in Northern Sweden}

The subject for this article is the forest commons established 1861-1918 in connection with the Great Redistribution of Land Holdings in the counties of Kopparberg and Gävleborg, and the delimitation process in the counties of Västerbotten and Norrbotten ( 11 AskL, SFS 1952:167). These commons are generally looked upon and grouped together with public forestland, e.g. in official statistics, and by that often incorrectly regarded as non-private property. However, the land belongs to the owners of the estates affected by the above-mentioned Redistribution of Land Holdings respectively the delimitation process ( $2 \S$ AskL, SFS 1952:167). Then again, management is performed jointly through elected boards and executed by professional foresters, and to some extent controlled by the Local Government. Further, property rights in the forest commons can only be transferred together with the private estate. The policy for how the dividend is used differs much due to their historical development and regional patterns can be discerned.

In the middle of the 19-th century the prize on timber went up drastically due to an international economic upswing (Wik, 1950) and a commercial exploitation of the Swedish forests, primarily driven by the forest companies and sawmill interests began. This caused a fear for irreversible depletion and degradation of the forests. (Östlund, 1993). At that time the state was finalizing the delimitation-process that involved the fixing of boundaries between the Crown land and other, but still the inner parts of Västerbotten (AC) and Norrbotten (BD) remained (Stenman, 1983). The process of delimitation of Crown land was preceded by yet another change of property

\footnotetext{
${ }^{1} \mathrm{PhD}$ student at the Dept. of Forest Resource Management and Geomatics, Swedish University of Agricultural Science, SE-901 83 Umeå, Sweden. E-mail: Eva.Holmgren@resgeom.slu.se

${ }^{2}$ Associate Professor at the Dept. of Silviculture, Swedish University of Agricultural Science, SE-901 83 Umeå, Sweden. E-mail: Gun.Lidestav@ssko.slu.se

${ }^{3}$ Forest Officer, Research Leader, Dept. of Forest Resource Management and Geomatics, Swedish University of Agricultural Science, SE-901 83 Umeå, Sweden. E-mail: Goran.Kempe@resgeom.slu.se
} 
rights, also almost finalized, the great redistribution of Land Holdings. This was the case in parts of the two counties Kopparberg and Gävleborg (W\&X). Both processes aimed to create bigger and more productive farms and by that strengthening the local economy and increasing the base of taxation to the Crown. (Liljenäs, 1982, Carlsson, 1995)

However, many of the farmers had already, in anticipation of the finalization of the above processes, sold cutting rights or farms to sawmill companies. In an attempt to put a halt to this development the authorities introduced the forest commons. ${ }^{4}$ Farmers would get one part of their forest share as individual owned land and the other as a share in a jointly owned area, a forest common. The idea was that these forests would be managed in such a way that they would provide a lasting sustainable base for the local farmers and strengthen the shareholders as well as the local economies, thus be protected from deforestation and degradation through good forest management (Liljenäs 1982, p. 70). Though, the introduction of forest commons could also be seen as a distrust of the farmers' capacity to manage their forests (Kardell, 1991).

Today, we have 33 forest commons covering about 540000 ha productive forestland (Ds Jo 1983:15) held by 25000 shareholders (Carlsson, 1999). All forest commons are under the same national laws and regulations, including the Swedish Forest Act, which regulates the management of Swedish forests. However, their formal organization and activities are regulated by a special law, the "Forest commons law" (SFS 1952:167), and in addition each forest common has its own by-law, authorized by the Local Government (Carlsson, 1995).

\section{The founding of Swedish Forest commons in the tree regions}

In 1858 a new law was approved by the Parliament with the intention to improve the economization of the local forest resources. After a decision from the Government, a number of forest commons were formed in $\mathrm{W} \& \mathrm{X}$ by setting aside about $1 / 3$ of the farmers allocated forestland under common custody. The reasons behind this decision were among other things to increase the farmer's interest for silviculture and good forest management (Liljenäs, 1982). The process went on during the period 1861- 1894.

\footnotetext{
${ }^{4}$ The Swedish forest commons can also be labeled "community managed forests" (Carlsson, 2001)
} 
In $\mathrm{BD}$, the local authorities headed by the County Governor, acted vigorously for the creation of forest commons in connection with the delimitation. In 1877 the Government gave his permission for voluntary formed forest commons in the areas still not delimitated in AC and BD. Thus, under active supervision from the BD County Governor, a big number of forest commons were created in BD, during the period 1876-1894 . They consisted of about $1 / 4$ of the allocated forestland. The dividend in BD should, like in $\mathrm{W} \& \mathrm{X}$ be divided to the shareholders as monetary subsidies for purposes benefiting the agricultural development like for drainage or agricultural training or to the public weal e.g. public assistance, assistance to electrification etc. (Liljenäs $1982)^{6}$.

In $\mathrm{AC}$ no forest commons were formed voluntarily. The County Governor did not actively work for it, and the sawmill companies worked forcefully against it. (Liljenäs, 1977, s 37-38) Finally, in 1906 a new law passed stating that in all not yet delimited forests, close to half of the allocated forestland should be given as a forest common. This law was applied in the four remaining municipalities in $\mathrm{AC}$ and in some newly colonized areas in $\mathrm{BD}^{7}$. These commons were established 1916-1918. According to the new law, the divided was paid to all shareholders as annual payments in relation to the size of their share in the forest common (Stenman, 1983).

\section{Regulations Affecting the Forest Management}

The establishment of the Swedish Forest commons began in W\&X in 1861 and ended 57 years later in AC (Liljenäs 1982, Carlsson, 1995). During this period many changes in general political conditions, forest legislations, economical and industrial development with respect to the forest industry, etc. took place. An increasing restrictiveness from the authorities concerning given benefits in connection with the land tenure reforms is becoming discernible. This was especially pronounced in the revised delimitation regulations for $\mathrm{AC}$ and $\mathrm{BD}$ from 1873, both with respect

\footnotetext{
${ }^{5}$ Corollary to a request from the local population in Pajala was a Forest common, after a special resolution from the Government, founded already in 1876 (Edman, 1880).

${ }_{7}^{6}$ Svärdsjö, Svartnäs and Envikens forest commons paid their dividend as annual payments to their shareholders.

7 Three smaller forest commons called "nybyggesallmänningar" were established in BD, in the municipalities Arjeplog, Gällivare and Jokkmokk (Lijenäs1982, p 60). Special regulations applied for these.
} 
to the size of the allocated forestland but also through the abolishment of the free right of disposal of the forests (utsyningslagen) (Arell, 1979). Trees could only be felled after permission from a forest officer. This made the forests less attractive to the sawmill owners but also to the farmers. Yet, for some reason did the law still permit the sale of farms or cutting rights that made it possible for the forest companies to speculate in forests. The sawmill companies were very active in buying private forestland and cutting rights from late 1880 up to 1900. In 1900, in the AC municipality Sorsele, was e.g. the size of the company property about $12 \%$ of the allocated land and they were in possession of the cutting rights to about $70 \%$ of the forestland allocated to farmers (Arell, 1979). This regulation for cutting rights expired 1949 (Arell, 1979).

The forest commons should according to the state intention be managed intensively by the use of management-plans aiming at high and even outputs (Ds Jo 1983:15, p. 67). However, the management was to a large extent in the hands of the Swedish Forest Service (Domänverket) who was superintending the above mentioned law concerning the disposal of the forests (utsyningslagen), there by was their own forest policy commonly used as guidance (Enander, 2001). The most commonly used management method was exploitation forestry or high-grading of forests, which was practiced in large parts of Sweden until the end of the 1940s. Such management often created open low productive forests (Enander 2001). Around 1950 the management strategy changed towards a system with clear cuttings, soil scarification, planting and pre-commercial thinning, transferring large areas into young even-aged forests dominated by pine and spruce. The forest policy applied by the forestry sector since that time aims at a sustainable production on a high and even level which requires a balanced age- and maturity class distribution.

Sweden got its first Forestry Act in 1903 which introduced regeneration regulations and later regulations for the protection of young forests were added. In 1948 was the law revised again, now to statute for even outputs and high economical profits through intensified silvicultural work leading to increased production. Production goals and conservation goals were both given equal importance in the revised Swedish Forestry Act of 1994 (Enander 2000, 2001). A guiding rule 
for the application of the law has been that the aims of the law if possible should be reached on the basis of conviction without using enforcement (Enander, 2001).

Of the above comes that the basic settings for the management of the various forest commons differ. This adds of cause up with differences in nature-given factors like in site productivity, distance to market or transportation, restrictions around management of forests in proximity of high mountains and areas difficult to regenerate or in considerations taken to the reindeer industry etc. We may also find other differences based on socio-economic, ethnic, traditional etc issues. All these factors must together have, directly or indirectly, affected the management of the various forests and together with the sum of actions taken (or not taken) may the product be visible by studying the forests.

\section{The research question, hypotheses and aim of the study}

In 1983 the Recommendation from the Swedish Commission on Collectively-Owned Forest Land (Ds Jo 1983:15, p.85) was published, where it among other things, was concluded that "Swedish forest expertise" regarded the Swedish forest commons to be "among the best managed forests in the country taken into consideration their prerequisites. Furthermore, that the annual cuttings rather constantly reached $100 \%$ of the approved management plans" ${ }^{\prime 8}$. Considering that the forest commons have been managed in accordance with the intentions for its management and to the Swedish Forest Act, a reasonable interpretation of this statement must be that the production capacity in terms of cuttings of the forests is fully used. However, Carlsson (1995) have calculated harvesting quotas (annual harvest volume/annual increment) from the forest commons for $1975-80^{9}$ and 1980-93 and these quotas indicates that only 3 out of 24 forest commons had harvesting quotas that supported such interpretation. A later study by Carlsson (1999 p.18) emphasize this findings, and he comments this situation as "puzzling that the commons only harvest a minor part of what they are allowed to do". In addition, he concludes, "In most of the cases there exists no significant correlation between prize and the size of the dividend. Taken as a whole, the Swedish forest commons do not pay their shareholders

\footnotetext{
${ }^{8}$ Our own translation from Swedish

${ }^{9}$ Carlsson use figures from Ds Jo 1983: 15 p. 86
} 
significantly more when prizes rise." Moreover, Carlsson claims that his data gives support to the target-income hypotheses (Carlsson, 1995). "The existence of a target income gives the effect that the shareholders can rely on even and predictable economic revenue, and at the same time over-harvesting is prevented". Following this, the question is how the levels on these target incomes has been set, and furthermore their impacts on the managements of the forest commons?

As mentioned above, the calculated harvesting quotas indicated a recurring imbalance between annual harvest volume and net annual increment. Additionally, the forest commons probably harvest less than they are allowed or have the potential to do. However, these quotas do not reveal much about the status of the forests. To get a better picture of the status of these forests and their management over time a more accurate and throughout method were needed. Furthermore, we also wanted a method that would allow us to compare the management carried out by different owner categories as well as different forest commons as a function of the institutional frameworks that they been under.

\section{Material and method}

A comparative study of the state of the forests in the Swedish forest commons and surrounding forests was undertaken. The research area covered all productive forest land within each municipality with a forest common, a total land area of about 4778600 ha divided roughly between three counties/regions as follows; the inner parts of the County of Norrbotten (BD, 2 $236300 \mathrm{ha}$ ), the inner part of County of Västerbotten (AC, $1014500 \mathrm{ha}$ ) and parts of the County of Kopparberg including a piece situated in the County of Gästrikland (W\&X, $1527900 \mathrm{ha}$ ). Only municipalities in each county/region with a forest common were included in the study. (Figure1)

The forestland was then divided into the four owner categories, non-industrial private forests (NIP forests), company forests, forest commons and public forests. The last owner category includes the Swedish State Land Management Agency and other types of public agencies. A number of forest parameters were compared between the four owner categories as well as 
between and within the three counties involved. The parameters studied were forest type, defined by tree species mixture, stand age (Hägglund, Lundmark (1981) J and maturity classes are two expressions for the stands degree of maturity. The forest over-storey inventory, where the trees are callipered and species registered, is used for volume and increment estimation. Increment cores from sample trees are used for increment estimations and to support age estimation at field. Potential yield or site productivity expresses the capability of a site to produce wood. The method used was based on worked up-data from the Swedish National Forest Inventory from the years 1998-2002 which is an all-encompassing annual inventory of Swedish Forest, carried out by the Swedish University of Agricultural Sciences (SLU). The objective is to provide basic data for research and planning and control of forest resources at a national and regional level. Despite five-year data, some estimates for small areas and uncommon phenomena have significant sample errors. Therefore, results from NFI should be based on data from at least 20 sample plots.

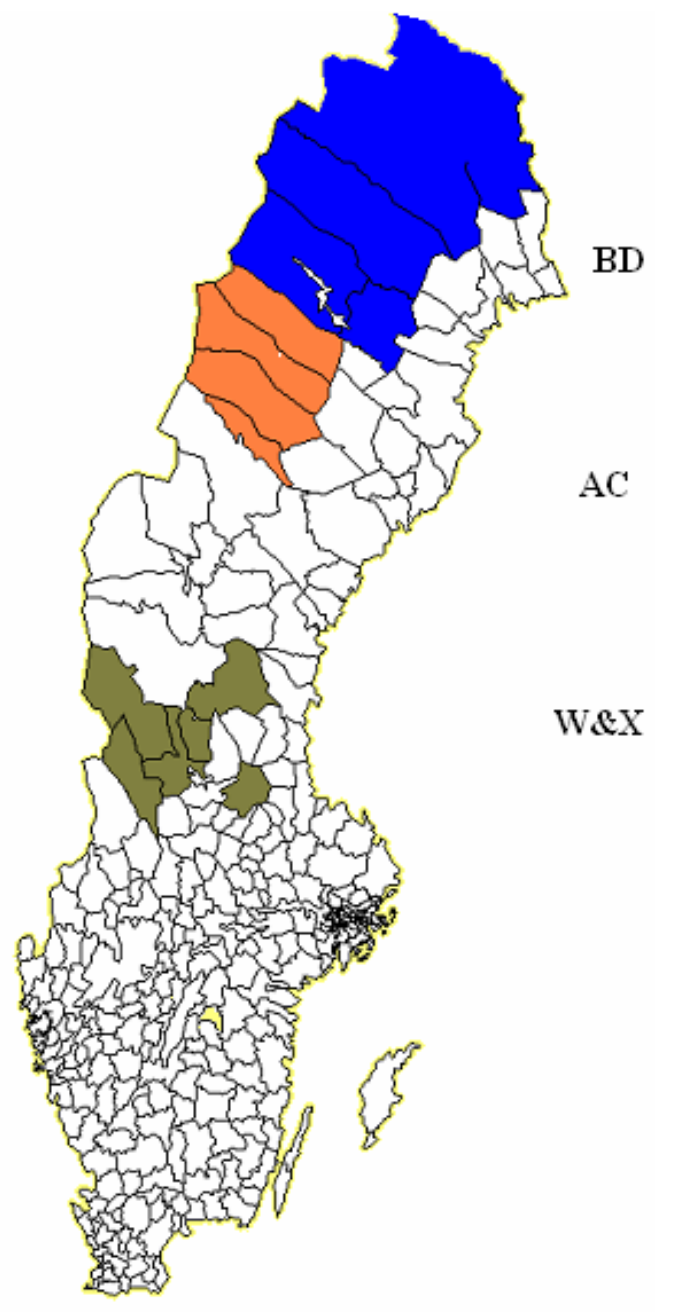


Figure 1. Municipalities with forest commons in the counties of BD (Norrbotten), AC (Västerbotten) and W\&X (Kopparberg \& Gävleborg) marked.

\section{Ownership structure}

The ownership structure in the studied area was as follows; forest commons $10 \%$, public forests $12 \%$, company forests $45 \%$ and non-industrial private forests (NIP forests) $33 \%$. BD had the lowest percentage of forest commons (7\%) while $\mathrm{W} \& \mathrm{X}$ had the highest $(13 \%)$ and $\mathrm{AC}$ (11\%)(figure 1). Company forests were the most common ownership type in BD while the NIP forests and company forest had a close to equal share (around 40\%) in $\mathrm{AC}$ and $\mathrm{W} \& \mathrm{X}$.

\section{Forest-types and site productivity}

The studied area is situated within the boreal forest region, dominated by stands of Scots pine

(Pinus Sylvestris L.) or Norway spruce (Picea abies (L.) Karst), sometimes mixed, and sometimes supplemented by broadleaved trees, mainly birch (Betula sp.). Broadleaved stands are rare, with the highest percentage (8\%) on NIP forestland in $\mathrm{BD}$ and $\mathrm{AC}$. In $\mathrm{W} \& \mathrm{X}$ and $\mathrm{BD}$, more than half the forestlands are pine stands. On the contrary spruce forests dominate in AC with the exception of the AC company forests, where 42 percent are pine and 27 percent spruce.

As expected, site productivity generally increased from the north to the south (figure 2). However, the AC forest commons had together with the BD public forests and the BD NIP forests the lowest mean site productivity in the whole study. The significantly highest mean site productivities of all were found on W\&X forests, particularly on NIP forests in W\&X.

Both the $\mathrm{AC}$ and $\mathrm{W} \& \mathrm{X}$ forest commons showed significant lower site productivity than the other forests within their respective regions. In AC no significant differences were found between the other ownership categories. Conditions were more complex in W\&X, as public forests did not differ significantly from the company forests. 


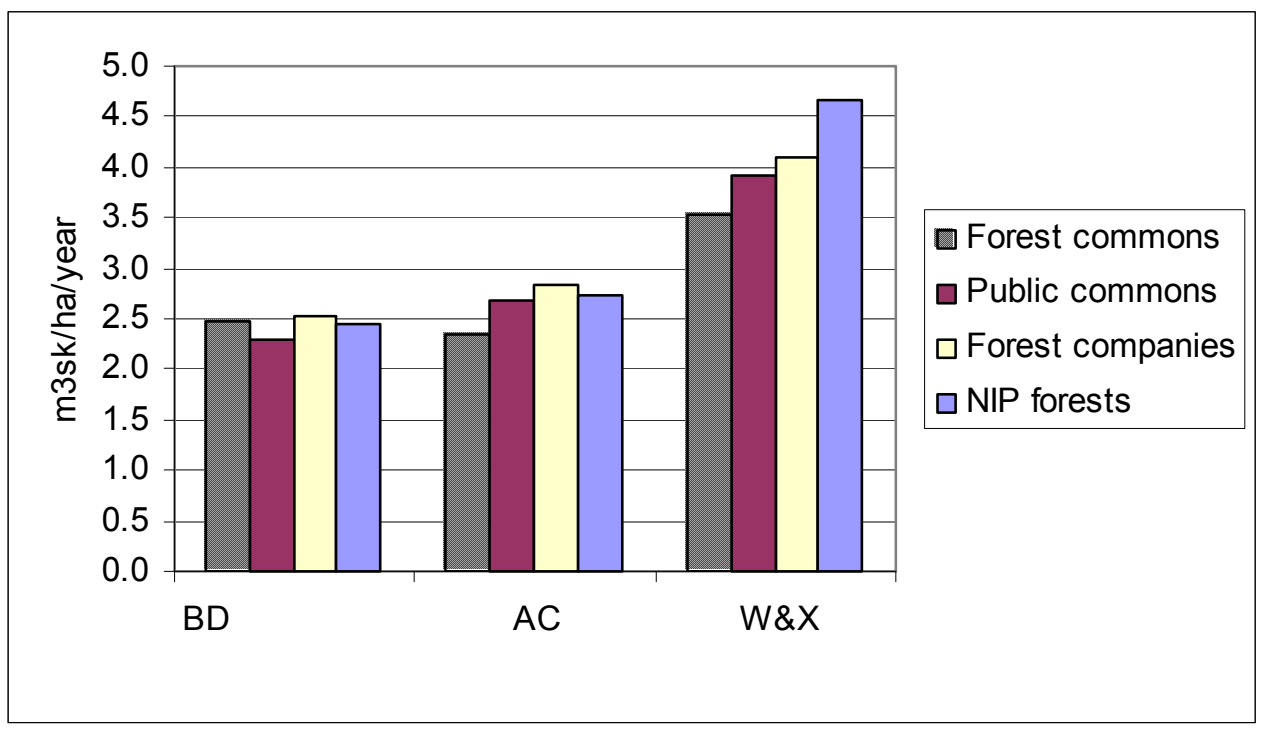

Figure 2. Mean site productivity by region and ownership category

\section{Forest land far from roads and close to mountains}

The distance to roads indicates the remoteness of the forests and also how active the forest management has been. The highest proportion of remote forestland ( $\geq$ and 1000 meters from roadside) is found on public forests in $\mathrm{BD}(43 \%)$ and forest commons in $\mathrm{AC}(44 \%)$. When it comes to forests above official boundary for forestland in the proximity of high mountains, did we find that the $\mathrm{AC}$ forests in general, and the $\mathrm{AC}$ forest commons in particular were closest to this boundary. Public forests in BD have also a large share of its forestland within this zone. 
Table 2 . Share of forestland with distance to roadside $\geq 1000 \mathrm{~m}$ respectively close to high mountains.

\begin{tabular}{|l|l|r|r|}
\hline Region & \multicolumn{1}{|c|}{ Owner } & $\begin{array}{r}\text { Distance to road } \\
\geq 1000 \mathrm{~m} \text { or more } \\
\text { (percent) }\end{array}$ & $\begin{array}{c}\text { Forest above official boundary } \\
\text { for forest land in the proximity } \\
\text { to high mountains (percent) }\end{array}$ \\
\hline BD & Forest commons & 32 & 12 \\
& Public forests & 43 & 32 \\
& Company forests & 21 & 7 \\
& NIP forests & 28 & 11 \\
\hline AC & Forest commons & 44 & 52 \\
& Public forests & 17 & 38 \\
& Company forests & 11 & 11 \\
& NIP forests & 12 & 26 \\
\hline XW & Forest commons & 5 & 0 \\
& Public forests & 8 & 8 \\
& Company forests & 5 & 2 \\
& NIP forests & 2 & 1 \\
\hline
\end{tabular}




\section{Age and maturity classes}

In $\mathrm{BD}$ and $\mathrm{AC}$, normal rotation-ages are normally 130 years and in $\mathrm{W} \& \mathrm{X} 120$ years. However, stand older 100 years or older are allowed to harvest by final felling. The age class distribution was characterized by a general lack of medium-aged forests and a surplus of forests older than 100 years (table3). Then again, the forest commons and public forests had the significantly highest percentage of old forests (100 years or older) while the company forests had the significantly lowest percentage. The most even age-distribution was found in the NIP- forests, particularly in the BD NIP forests.

Table 3. Forestland area by age classes within owner categories and regions during the period 1998-2002.

\begin{tabular}{|c|c|c|c|c|c|c|c|c|}
\hline \multirow[b]{2}{*}{ Region } & \multirow[b]{2}{*}{ Owner } & \multirow[b]{2}{*}{$0-20$} & \multicolumn{5}{|c|}{ Age Classes (Years) } & \multirow[b]{2}{*}{$141-$} \\
\hline & & & $\begin{array}{r}21- \\
40\end{array}$ & $\begin{array}{r}41- \\
60\end{array}$ & $\begin{array}{r}61- \\
80\end{array}$ & $\begin{array}{l}81- \\
100\end{array}$ & $101-140$ & \\
\hline \multirow[t]{4}{*}{$\overline{\mathrm{BDD}}$} & Forest commons & 20 & 15 & 12 & 12 & $\overline{77}$ & 16 & 18 \\
\hline & Public forests & 8 & 17 & 12 & 5 & 9 & 27 & 22 \\
\hline & Company forests & 19 & 23 & 18 & 11 & 6 & 13 & 10 \\
\hline & NIP forests & 18 & 11 & 15 & 16 & 13 & 17 & 10 \\
\hline \multirow[t]{4}{*}{$\mathrm{AC}$} & Forest commons & $5^{10}$ & 7 & 6 & 6 & 14 & 40 & 22 \\
\hline & Public forests & 18 & 14 & 2 & 3 & 6 & 37 & 20 \\
\hline & Company forests & 33 & 21 & 10 & 3 & 6 & 20 & 7 \\
\hline & NIP forests & 22 & 10 & 9 & 5 & 11 & 33 & 10 \\
\hline \multirow[t]{4}{*}{ W\&X } & Forest commons & 23 & 20 & 7 & 7 & 6 & 27 & 10 \\
\hline & Public forests & 26 & 21 & 10 & 8 & 6 & 21 & 8 \\
\hline & Company forests & 27 & 19 & 8 & 7 & 11 & 20 & 8 \\
\hline & NIP forests & 26 & 15 & 10 & 9 & 11 & 21 & 8 \\
\hline
\end{tabular}

\footnotetext{
${ }^{10}$ Figures marked in italics are estimations based on less than 20 observations and the proportion should therefore be interpreted with caution.
} 
BD displayed the generally most even age-distribution among the three regions studied and the $\mathrm{BD}$ forest commons displayed the most even distributed age pattern among the forest commons. In $\mathrm{AC}$, we found the most uneven age patterns with the exception of AC company forests. They followed the same pattern as the other company forests in the study with rather low percentages of old forests and comparatively much young forest. The $\mathrm{AC}$ forest commons and $\mathrm{AC}$ public forests had a significantly higher percentage of old forest (100 years or older) than the AC company forests. Only $24 \%$ of the AC forest common was younger than 80 years. This certainly indicates that the $\mathrm{AC}$ forest commons, since they were established 80 years ago have been restrictive regarding clear cuttings. While other forest-owners display an increased activity in regeneration (age-class 0-20 respectively 21-40), the AC forest commons continuously show low.

Due to site productivity, altitude, latitude and the tree species, the stands are regarded as mature for final felling at different stand ages. Therefore the distribution on maturity class gives better information than age class, on the potential for final felling, thinning and other silvicultural measurements. Considering sustainable, high and even outputs the ideal figure for mature forest would be approximately $30 \%$ if the rotation period is set to 100 years.

In figure 3 forests mature for final felling is presented showing large differences between regions and owner categories. The biggest disparity within a region was found in $\mathrm{AC}$ where $75 \%$ of the forest commons were mature for final felling compared to $30 \%$ of the company forests. Also the public forests in $\mathrm{AC}$ had a very high share of forest for final felling. About $50 \%$ of the NIP forests in $\mathrm{AC}$ and the public forests in $\mathrm{BD}$ were mature for final felling, while other owner categories in BD display less percentages of mature forests. Differences between owner categories in W\&X were not significant nor exceptionally high. However, considering the idea of sustainable, high and even outputs BD and AC public forests, AC NIP forests and in particular the $\mathrm{AC}$ forest commons have too much mature forests and consequently too little younger forests. 


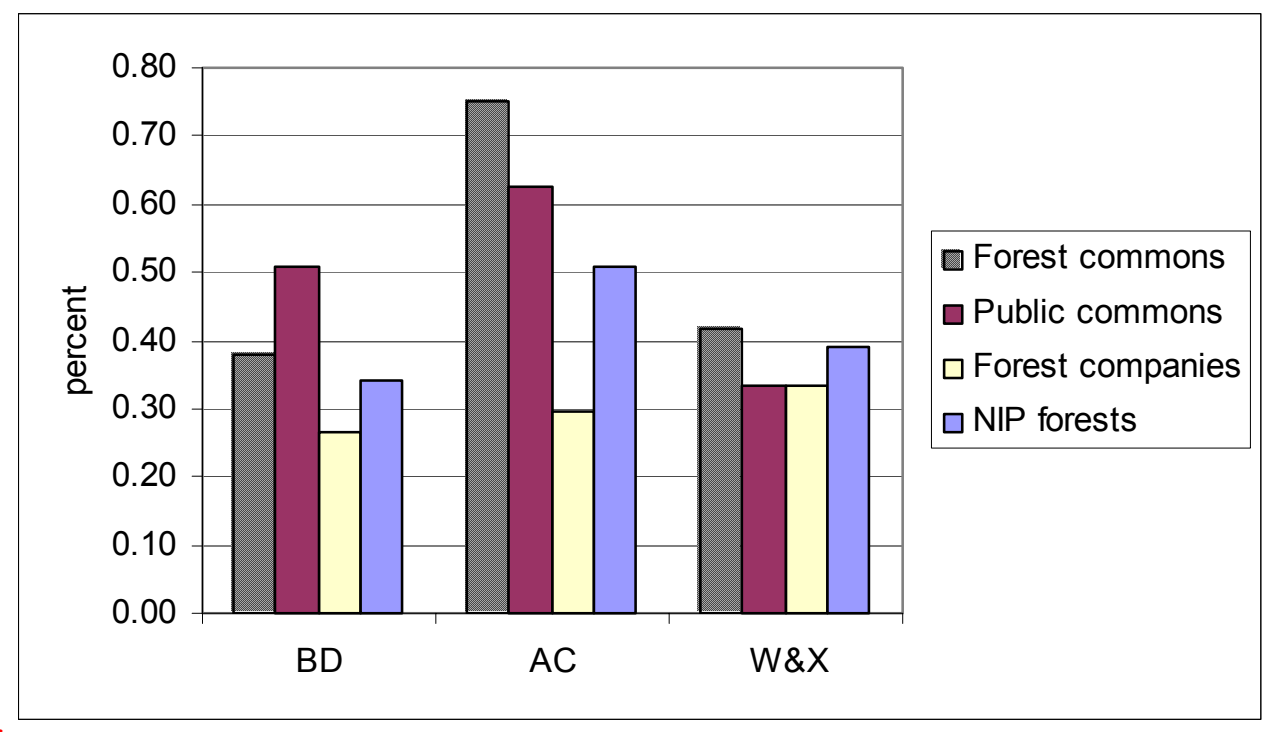

Figure 3. Percent of forestland area with forest mature for final felling, within ownership category and counties and regions during the period 1998-2002.

\section{Standing Volume per hectare}

Obviously, standing volumes per hectare increases with age. Therefore, forest estates with a higher share of older or mature stands, are more likely to have a higher mean standing volume. A reasonable comparison should therefore be based on standing volumes within each age-class. If not, incorrect conclusions may be drawn regarding the management e.g. to conclude that the AC forest commons with a mean standing volume of $90 \mathrm{~m}^{3} /$ ha is better managed than $\mathrm{AC}$ company forests with a mean standing volume of $70 \mathrm{~m}^{3} \mathrm{sk} / \mathrm{ha}$. However, the figures for standing volumes within age-class shows that the AC forest commons consistently have lower values than the AC company forests, in fact lower than all the others. Furthermore, the AC public forests, which are rather similar in terms of site productivity and close proximity to high mountains, have much higher standing volumes in most age-classes. 
Table 4. Standing volume per hectare of forestland within age classes, ownership categories and counties and regions during the period 1998-2002 (m3/ha).

\begin{tabular}{|c|c|c|c|c|c|c|c|c|c|}
\hline \multirow[b]{2}{*}{ Region } & \multirow[b]{2}{*}{ Owner } & \multicolumn{8}{|c|}{ Standing volume per hectare $(\mathrm{m} 3 / \mathrm{ha})$} \\
\hline & & $\begin{array}{l}0- \\
20\end{array}$ & $\begin{array}{c}21- \\
40\end{array}$ & $\begin{array}{c}41- \\
60\end{array}$ & $\begin{array}{l}61- \\
80\end{array}$ & $\begin{array}{l}81- \\
100\end{array}$ & $\begin{array}{l}101- \\
140\end{array}$ & $141-$ & Total \\
\hline \multirow[t]{4}{*}{$\overline{\mathrm{BD}}$} & Forest commons & 13 & 13 & $\overline{51}$ & 82 & 110 & 125 & 114 & 68 \\
\hline & Public forests & 11 & 30 & 52 & 86 & 92 & 99 & 107 & 75 \\
\hline & Company forests & 10 & 25 & 65 & 87 & 98 & 120 & 116 & 62 \\
\hline & NIP forests & 11 & 26 & 56 & 73 & 102 & 113 & 122 & 69 \\
\hline \multirow[t]{4}{*}{$\mathrm{AC}$} & Forest commons & $9^{7}$ & 8 & 25 & 78 & 91 & 116 & 107 & 90 \\
\hline & Public forests & 8 & 73 & 126 & 92 & 94 & 153 & 185 & 117 \\
\hline & Company forests & 10 & 28 & 62 & 100 & 132 & 161 & 176 & 70 \\
\hline & NIP forests & 9 & 37 & 98 & 102 & 97 & 122 & 131 & 84 \\
\hline \multirow[t]{4}{*}{ W\&X } & Forest commons & 9 & 45 & 92 & 129 & 109 & 143 & 161 & 87 \\
\hline & Public forests & 15 & 50 & 123 & 132 & 159 & 112 & 159 & 83 \\
\hline & Company forests & 16 & 62 & 119 & 158 & 167 & 183 & 142 & 102 \\
\hline & NIP forests & 18 & 64 & 153 & 186 & 190 & 192 & 216 & 146 \\
\hline
\end{tabular}

\section{Discussion and conclusions}

Taken as a whole, results show that the status of the forests in the AC forest commons differs from the surrounding forests in $\mathrm{AC}$, but also differs in relation to other forest commons. This can be concluded, in spite of the un-security regarding the estimation of some parameters due to a small number of observations. As the present status of a forest inclusive proximity to roadside, to a large extent depends on the management performed, we interpret these differences mainly as a result of different management strategies. Long distance to road indicates low harvesting activity, but crucial to any harvesting operation is the profitability, which to a large extent depends on the market situation and the distance to the processing industry. However, we must also consider that the nature-given factors, i.e. site productivity, altitude, and close proximity to high mountains are somewhat less favorable on AC forest commons. Whether this is a result of 
the conditions at hand when the commons were created, cannot be determined by this study. However, we do know that the AC forest commons were established late, in an advanced stage of the exploitation process. The authorities' low interest for the forest commons, and the company forests strong position in AC (Liljenäs, 1977) may have been decisive to the outcome of the process. Later on, considerations to reindeer husbandry, the tourism or demands on environmental protection may also have an impact, but are not analyzed in this study.

The differences in nature-given conditions have certainly influenced the state of the AC forests commons, but probably not been decisive. This interpretation is based on results regarding BD public forests and BD NIP forests, which also have low mean site productivity, and in the case of the BD public forests large areas in close proximity of high mountains. Regarding age-structure, forests mature for final felling and standing volume, they are not as extreme as the AC forest commons.

The expressed objective for the forest commons was to create sustainable, well managed forests. Furthermore, they were supposed to produce a high and even output due to proper management. (Ds Jo 1983:15). Therefore it can be assumed that they, likewise other forests, have been managed according to the existing Swedish Forest Act. On the basis of our results, and our assumptions, it can be questioned if the conclusions drawn by the Swedish Commission on Collectively-Owned Forest Land are correct. Our results do not support the statement that the forest commons are "among the best managed forests in the country taken into consideration their prerequisites" (Ds Jo 1983:15, p.85). Further, that a general conclusion about the management or the institution itself hardly can be made, as regional differences are large.

In accordance with Carlsson (1995), no indications of over-harvesting were found. On the contrary, the distribution on age- and maturity classes and standing volumes in age-classes rather indicates too restrictive harvesting policy given "high and even output". If this is due to a pre-set target income, as suggested by Carlsson (1995), the level on the target has to be questioned. Particular the situation on the AC forest commons should be revised. In this context, the impact of different policies for how the dividend is distributed, as annual payments or as monetary subsidies, should be regarded. 


\section{References}

Lag (1952:167) om allmänningsskogar i Norrland och Dalarna, Svensk Författningssamling (SFS) 1952:167

Arell, N.(1979), ‘Kolonisationen i lappmarken’, Esselte Studium AB, ISBN 91-24-29597-3

Carlsson, L. (1995), 'Skogsallmänningarna i Sverige', Forskningsrapport Tulea 1995:22, ISSN 0347-0881.

Carlsson, L. (1999), 'Still going strong, community forests in Sweden', Forestry, 72(1):11-26.

Enander, K-G. (2000), 'Skogsvårdslagen 1903 - dess förhistoria och några huvuddrag I utvecklingen', Swedish University of Agricultural Sciences, Dep. of silviculture, Reports, No. 46.

Enander, K-G. (2001), 'Skogsbrukssätt och skogspolitik 1900-1950', Swedish University of Agricultural Sciences, Dep. of silviculture, Reports, No. 48.

Hägglund, B., Lundmark, J.-E., 1981. Handledning i bonitering med Skogshögskolans boniteringssystem. National Board of Forestry, Jönköping, Sweden.

Kardell (1991) skogshistoriska skiss. Lima-Transtrand. I: Petterson T.J. (red). Ur två socknars historia. 3(1991) s. 103-182. Malungs kommun. Malung

Liljenäs, I. (1977), 'Allmänningsskogarna i Norrbottens län - deras betydelse för det enskilda jord- och skogsbruket', Kungliga Skytteanska samfundets handlingar, No 16, 1977

Liljenäs, I. (1982), 'Besparingsskogarna I Kopparbergs och Gävleborgs län samt allmänningsskogarna I Norrbottens och Västerbottens län', Gerum, Rapport A:34, ISSN 03480887. 
Skogsallmänningar - Betänkande av allmänningsutredningen (Ds Jo 1983:15), Ministry of Agriculture, ISBN 91-38-08096-6

Stenman, L. (1983), 'Delimitation in the Lapland region of the county of Västerbotten' Forskningsrapporter från Kulturgeografiska institutionen, Uppsala universitet, 83

Wik, H. (1950), 'Norra Sveriges sågverksindustri från 1800-talets mitt fram till 1937', Geographica 21. Stockholm

Östlund, L. (1993), 'Exploitation and structural changes in the north Swedish boreal forests 1800-1992', Dissertations in Forest Vegetation Ecology 4, Swedish University of Agricultural Sciences, Umeå, Sweden 